\title{
A Study of Key Subject Construction Oriented Document Resource Construction of University Libraries
}

\author{
Xinyu Wang, Qingsong Zhang \\ library, \\ JiLin Agricultural University , \\ Changchun, China \\ Email: wangxinyu8303@126.com; Email: 1007738301@qq.com
}

Key words: university library; subject service; literature resources construction

\begin{abstract}
This paper makes an introduction to the importance of the construction of literature resources in subject services of university library and the concrete contents of subject resource construction , presents some measures for perfecting literature resource construction .
\end{abstract}

\section{Introduction}

Subject service, is value-added service, which involves the users' decision making process where it helps them find or set the solution. It is based on the collection of library resources and network resources, driven by the users' needs, and with the orientation of knowledge content. Subject service follows the process of subjects, rather than that of the document work process to organize scientific and technological information. Service in the scientific and knowledgeable way will improve the information service in the supportive rate of the users' demands and tasks[1]. The Features of subject service mainly show in the three aspects of research, academic and knowledge. The specific forms of subject services include the resource establishment of subject, resource navigation of subjects, subject consultation, project investigation, trend analysis of study, frontier tracking of subject, etc., among which the resource establishment of subject ranks the first. This shows its great importance in the subject service. Subject service is a currently emerged service mode in the libraries in China. The service mode of subject librarian is the main way subject information service, and the resource establishment of subject ensures the document resources for the subject service.

\section{The function of the resource establishment of subject in the subject service}

\section{A. The function of resource support}

The construction and application of subject service require extensive literature resources as a guarantee. The service determines the resource, and the resource guarantees the security. The library resource with subject services has its own characteristics. It has the advantages in key subjects. The diversified collection structure which includes digital resource, network resource and printed document resource, makes the library information resources rich and convenient to get. Thus, the construction of subject resource will guarantee subject service in terms of library resource ${ }^{[1]}$.

\section{B. The function of mutual promotion}

Through the subject service, the university libraries connect themselves to the particular readers as a whole, forming a virtuous cycle of interaction. In this way, it not only provides a personalized professional service to the readers by meeting their needs, but also improves the construction of library resources and human resources. This leads the development process of the library reform to a further personalized, scientific and systematic one. The purchasing 
purposefulness of books, journals and databases is enhanced by the interaction and communication between the libraries and the readers. To avoid the subjective blindness in purchasing improves the utilization rate of library resources. The subject service is the inevitable demand for bettering the construction of library resources and for developing sustainably ${ }^{[2]}$. Therefore, it not only provides a personalized professional service to the readers by meeting their needs, but also improves the construction of library resources and human resources.

\section{The content of document resources construction under the subject service}

The document resource of subjects collected in the university libraries can let the researchers understand and master the front information and development trend of subjects at home and abroad, inspire researchers in teaching and researching. It offers help to make sure of the research tops and their research direction, improve the work efficiency, and finally advance the construction of the key subjects.

\section{A. The investigation research of the subject resources}

The subject librarians should make sense of the running principle of their universities, understand and master the composition of key subjects, and the needs of the users who are involved in the key subjects on aspects of document types, information services. They should so some research on their schools' subject setting, professional setting, curriculum setting. They should come closer in the departments, involving in teaching and research. They should making plans to visit the department leaders, academic leaders and backbone teachers, in order to establish close links with the teachers and students and academic leaders of the key subjects. In this way, the documents for the users of subject resources can be established gradually. The librarians should do the research on subject resources of library collection. And they should make an overall plan of subject resource development, the system, type configuration and collection range of subject documents. These all follow the objectives of subject development and teaching and research needs, meanwhile with the comparison and supplement of the existing collections or available resources ${ }^{[3]}$.

\section{B. The storage and purchase of the subject resources}

The subject librarians communicate with the interviewed departments, and provide guidance for the planning and guaranteed construction of the subject resources. They may purchase books right in the suppliers' together with the backbone teachers. For the book and journal list collected and summarized from the interviewers, the first step is to classify the list into several according to the corresponding departments, which then will be given to the lecturers of different majors. And finally, the analysis and the summary of the list will be shown to the interviewees. As for the electronic resources, the librarians should test or organize and try them. Before purchasing, collecting the readers' opinions comes first. They should organize and analyze the recommended resources by the readers, mastering the features of their needs, so as to propose reasonable purchasing advice. These methods, on the one hand can satisfy the readers' needs, on the other hand, can make up the lack of professional knowledge of interviewees.

\section{The promotion of subject resources}

The subject librarians, through the network platform, establish the navigation of the network resources of subjects and the guidelines of their library resources and disseminate and recommend the subject resources of quality. These resources covers different types of carriers, including foreign language books, foreign language journals, Chinese books, theses on the important conference, electronic resources, etc.

\section{The evaluation of subject resources}

The quality of subject resources directly affects the full utilization of the library documents and the accordance with the readers' needs. The evaluation of subject resources is an indispensable step in the construction of document resources ${ }^{[4]}$. The methods of it are the library structure analysis, the number of documents in circulation, readers' questionnaires, etc.. They are used to evaluate the 
quantity, document structure, document utilization and readers' satisfaction. And they function in identifying the gaps between the set objectives and the actual results, revealing weaknesses of library document quality, and amending, improving and bettering the document construction. The results come into the policy for particular document development, the perfection of document information security system, optimizing of the collection structure and improvement of the utilization rate of the library collections.

\section{The measures to better the construction of document resources of subjects}

A. Strengthening the collection of documents with characteristics, to from distinguished library collections with the objectives of profession and characteristics.

According to the realities of each library, the construction of document resources is based on improving and optimizing the paper documents in the libraries, while also based on the existing collections. The librarians should make full preparation of the precise investigation, determine the specific service target, make sure of the information needs of readers, and list the expense of the distinguished documents. Closely related to the characteristics of "local" and "academic", they should make a selective collection and organization of the documents of local characteristics. The efforts of collection should be paid increasingly to enrich the document base.

\section{B. Training librarians' cultural awareness in order to establish a subject librarian team of high} quality, and with rational structure

A subject librarian team should be built. They have a distinctive characteristic subject background and are familiar with the means to use the library collections and resources, with a keen sense of information awareness and a strong ability of processing the documents. They can provide initiatively the researchers of particular subjects with the further professional document-level information services ${ }^{[5]}$. By establishing an interactive platform with the subject leaders and experts, they will get the development plan of the subjects and the readers' needs, and offer consultation for the subject experts. Moreover, under the circumstance of not affecting the daily work, they should enhance the personnel training, organize the staff to learn the related content, including the theories of library information services, to improve their capabilities of information service. Only with the reasonable personnel structure, and more patience and initiation, the librarians will be in the better use. The consultation for the subject experts will be offered in a more efficient way. And the library resources and services will be full enjoyed by the readers.

\section{Integrating and developing distinguished document resources, to create the virtual library collections and the databases with the characteristics of particular subjects}

The distinguished document resources are the unique documents among the professional ones, which focus on their specialties. Based on the readers' needs, the distinguished documents are arranged and processed according to their types, in different methods and into different depth. The more they activate the dynamic information and intelligent sources, the higher the utilization rate of them. Through showing their own advantages of the talents and the distinguished documents, the librarians should select, sort, classify, index the existing library resources and the dispersed online resources related to the distinguished subjects. Thus, they will make them in order and systematic, and vast network of information resources get the further development. Gradually, they become closer to the electronic information resources and network information resources, and adopt them to the library collection range. Finally, a virtual collection is formed, which is convenient to facilitate teachers and researchers, making the network resources and library resources are interdependent and mutually reinforced, to meet the needs of the subject construction and scientific research in a better way.

\section{Enhancing the cooperation and exchanges among the libraries, to achieve resource sharing}

The cooperation among the libraries and resource sharing under network environment are essential to guarantee the expansion of the subject documents with characteristics. In so doing, the 
purpose of it is to reduce the waste of resources, and more importantly to meet the needs of teaching and researching in a better way. In fact, the cooperation among the libraries and resource sharing is the inevitable trend of the future development of the libraries. They are also the actual needs for strengthening the overall power of the libraries in China and for improving the service benefits.

\section{Conclusion}

In short, the universities' undergoing the distinctive development is an inevitable trend. And their libraries must adapt to it, by basing on the development of the distinguished resources of their own, while setting the distinguished information service goal, and carrying out the services for readers with their own characteristics. Only in this way, the developing direction can be found in the process of their distinguished development. They will contribute in the construction of library and service system with their own characteristics which is compatible with the school's development.

\section{Acknowledgements}

This paper is the research finding of the 12th Five Year Plan of education science in Jilin Province "The construction and practice of support platform of universities' library rescourse and service facing to the construction of key disciplines" in the year of 2015 (Item Number: GH150212) and the research project of National Agricultural Literature Information Center of CALIS "The deep integration and further research of the library resources under the background of Big Data” in the year of 2015 (Item Number: 2015019)

\section{References}

[1] Guo Jing. Research and Development of library science Service, [M]. Shanghai: Profile of Shanghai Jiao Tong University Press, 2013: 69 - 70.

[2] Sun Quan. Mechanism of Subject Librarian's participation in Literature Resources Construction [J]. 2014, (1): $41-44$.

[3] Wang Xingwang, Li Zhenglong, Shen Yunrui. On the current situation and Countermeasures of Document Resource Construction in Colleges and Universities oriented for Discipline Construction, [J]. Journal of Library Science, 2013, (2) : 42- 44.

[4] Zhu Hongye. On the construction of distinctive and advantageous university discipline Libraries, [J]. Tu Shu Guan Lun Tan, 2007, (4): 42-44.

[5] Zhao Hongxin. On Higher Vocational College Library Information Resources Construction under the Network Environment, [ J ] . Library Work and Study, 2009 (9): 34-35. 